\title{
Library Records Prepared with the Aid of Data Processing Equipment
}

\begin{abstract}
Published reports are examined on twenty-five projects for utilizing machines in library records maintenance. Advantages and disadvantages and cost of development and operation are noted; reasons for introducing machines are summarized. All show improvement in service, eighteen report savings, fourteen render better inventory control. Ten reports, however, give no cost data, and only six give comparative costs. Nonetheless, summation indicates that data processing by machine can be advantageous in library record keeping when two conditions exist: 1) a basic record can be used for a variety of purposes; and 2) cost of development and programing can be shared by a number of libraries. An index to the cases is appended.
\end{abstract}

$\mathrm{T}$ HE USE OF DATA PROCESSING equipment for the preparation of acquisition, cataloging, circulation, and related library records is frequently suggested to libraries of various types and sizes as a means for improving such records as well as for more efficient utilization of library manpower. Has experience with such systems borne out this hope and, if so, what is involved in developing and operating machine-based library record systems? The present study attempts to answer these questions by summarizing and commenting on case histories of machine-based library record systems. The literature since 1960 was searched for case histories of machine-based library records systems that are reported to be at least in the experimental stage and that are not primarily concerned with indexing systems. A bibliography

Gerald Jahoda is Professor of Library Science in Florida State University, Tallahassee, and Ferrol Ann Accola is with the Federal Reserve Bank Library in Atlanta, Georgia. prepared by McCormick $^{1}$ was updated by searching Library Literature and $\mathrm{Li}$ brary Science Abstracts, and by scanning a select number of current periodicals through March 1964. No claim is made for completeness, and the tabulation of data required interpretation that, it is hoped, has not done injustice to the original author's intended meaning.

In the summarized case histories of the twenty-five installations, the libraries are characterized as government, industrial, public, or university libraries unless the type of library is obvious from its title. The status of the machine-based record is characterized as experimental, partly operational, or operational. The date of initiation of operational systems is indicated whenever this is given in the original document. Library records produced with the aid of data processing equipment are listed next. The records

\footnotetext{
1 Edward M. MeCormick, "Bibliography on Mechanized Library Processes," Proceedings of the 196s Clinic on Library Applications of Data Processing, ed. Herbert Goldhor (Champaign, Ill.: Illini Union Bookstore, 1964), pp.157-76.
} 
are grouped for convenience by use with books, reports, and serials. The volume of the operation is also given when available and in whatever form this was indicated in the original document. The case histories are followed with references to the original documents.

The summarized case histories are also indexed by type of library and type of record prepared with the aid of data processing equipment.

\section{Summarized Case Histories of} TwENTy-Five InStallations

1. Atomic Energy Research Establishment, Harwell, Great Britain (government)

Status: Operational

Operations: Serials-acquisitions

-complete holdings

-current list

Volume: $\quad 1,400$ serial titles, 3,200 copies

Reference: L. J. Anthony and J. E. Hailstone, "Use of Punched Cards in Preparation of Lists of Periodicals," ASLIB Proceedings, XII (October 1960), 34860.

2. IBM Data Systems Division, Technical Information Center, Poughkeepsie, New York

Status: Operational

Operations: Books-catalogs (on cards and in book form)

-bibliographies

-circulation

-announcement lists

References: Robert E. Durkin and Herbert S. White, "Simultaneous Preparation of Library Catalogs for Manual and Machine Applications," Special Libraries, LII (May-June 1961), 231-37.

Herbert S. White, "The Use of Mechanized Equipment in the Production of Library Records for Manual Handling or Computer Manipulation" (paper presented at the Florida State University Conference on Organization and Utiliza- tion of Information, Tallahassee, Florida, January 9-11, 1964). 8p.

3. General Electric Company, Locomotive and Car Equipment department library, Erie, $\mathrm{Pa}$.

\section{Status: Operational}

Operations: Serials-circulation

-bindery records

-budget records

-routing

Reference: Ronald J. Booser, "The Use of Data Processing Equipment for Control and Circulation of Magazines," Special Libraries, LI (July-August 1960), 297-300.

4. National Research Council library, Canada (government)

Status: Partly operational Operations: Serials-acquisitions

-current list -complete holdings

Volume: 10,000 serial titles ( 80 per cent of total holdings)

Reference: Jack E. Brown and Peter Walters, "Mechanized Listing of Serials at the National Research Council Library," Canadian Library, XIX (Winter 1963), 420-26.

5. U.S. Army Missile Command, Redstone Scientific Information Center, Redstone Arsenal, Alabama

Status: Partly operational

Operations: Serials -acquisitions

-claiming

-bindery records

-routing

-complete holdings

Books -acquisitions

-in-process records

- catalog (in book form)

-accession list

- circulation

-budget records

-selective dissemination of information 


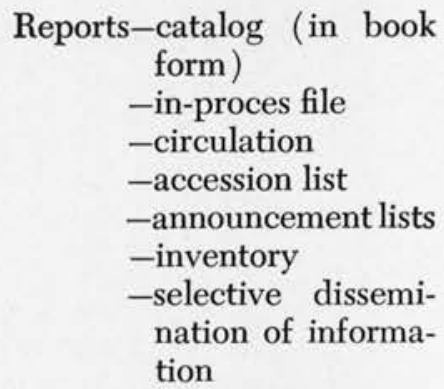

Reference: F. E. Croxton, Automation Progress at RS1C; the Status of Alpha 1 (Redstone Arsenal, Ala.: U.S. Army Missile Command, 1963), 11p.

6. Sandia Corporation, Albuquerque, New Mexico

Status: Partly operational

Operations: Serials-acquisitions

-budget records

-current lists

-routing

-complete holdings

Books - catalog (on cards and in book form)

-circulation

-announcement lists

Volume: $\quad 7,000$ journal copies of 1,500 titles are routed to 1,300 recipients

References: Crowell Dean, "Integrating a Library Machine System," The Literature of Nuclear Science: Its Management and Use (Oak Ridge, Tenn.: U.S. Atomic Energy Commission, Division of Technical Information Extension, 1962), pp. 165-67.

William H. Richardson, "Circulation Control," Special Libraries, LI (November 1960), 493-96.

7. Lockheed Aircraft Corporation, Scientific and Technical Information department, Marietta, Ga.

\section{Status: Operational}

Operations: Serials -budget records

-subscriptions expiration dates

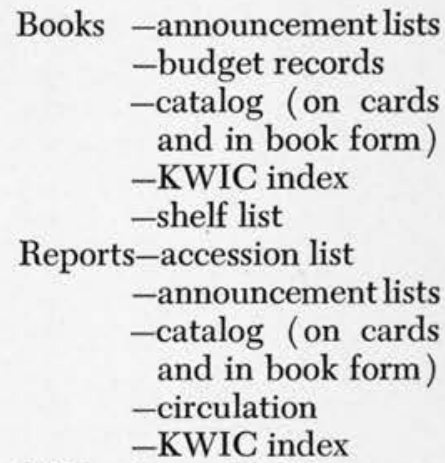

Volume: $\quad 150$ books and 1,250 reports added monthly; 500 journal subscriptions

Reference: C. K. Bauer, "Practical Applications of Automation in a Science Information Center-A Case Study," Special Libraries, LV (March 1964), 137-42.

8. Air Force Cambridge Research Laboratory research library, Hanscom Field, Massachusetts

Status: Experimental

Operations: Books-catalog (on cards)

- KWIC index

Volume: 180,000 monographs and bound journal volumes; 2,500 monographs added yearly

Reference: Paul J. Fasana, "Automating Cataloging Functions in Conventional Libraries," Library Resources and Technical Services, VII (Fall 1963), 350-65.

9. National Reactor Testing Station technical library (operated for U.S. Atomic Energy Commission by Phillips Petroleum Company's Atomic Energy Division)

Status: Partly operational

Operations: Serials -acquisitions

-claiming -bindery records

- circulation

- current lists

-holding lists 

Books -announcement lists -catalog (in book form)
-acquisitions
-budget records
- circulation
-subject authority file
Reports-circulation

Reference: Hillis L. Griffin, "The National Reactor Testing Station Technical Library," Pacific Northwest Library Association Quarterly, XXVI (July 1962), 199-204.

10. Picatinny Arsenal, Technical Information section, Dover, New Jersey (government)

Status: Operational (April 1962)

Operations: Serials - circulation

Books - circulation

Reports-circulation

Volume: $\quad 29,000$ books

900 current periodical

135,000 technical reports

114,000 separate library transactions a year

Reference: J. Hazendari and H. Voos, "Automated Circulation at a Government R and D Installation," Special Libraries, LV (February 1964), 77-81.

11. University of Illinois, Chicago undergraduate division library

Status: Experimental

Operations: Serials-acquisitions

- claiming.

-bindery records

-current lists

-complete holdings

Books - acquisitions

-catalog (in book form)

-circulation

-budget records

-permuted LC headings index

-selective dissemination of information -analysis of readers' interests

-bibliographies

-in-process records

Volume: 6,500 serial titles bound each year

References: Don S. Culbertson, "Data Processing for Technical Procedures at the University of Illinois Library," Information Retrieval Today (paper presented at the institute conducted by the library school and the Center for Continuation Study, University of Minnesota, Minneapolis, September 19-22, 1962), pp.99-107.

Edward Heiliger, "Application of Advanced Data Processing Techniques to University Library Procedures," Special Libraries, LIII (October 1962), 472-75.

12. Los Angeles (California) County public library

Status: Operational

Operations: Serials-complete holdings Books-catalog (in book form)

Volume: $\quad 2,000,000$ volumes

7,500 adult titles acquired each year

References: Theodore Hewitson, "The Book Catalog of the Los Angeles County Public Library: Its Function and Use," Library Resources and Technical Services, IV (Summer 1960), 228-32.

Catherine MacQuarrie and Beryl L. Martin, "The Book Catalog of the Los Angeles County Public Library: How It Is Being Made," Library Resources and Technical Services, IV (Summer 1960), 208-27.

13. Decatur (Illinois) public library

Status: Operational

Operations: Serials-complete holdings

-circulation

Books - acquisitions

-catalog (in book form)

-circulation

-budget records 
Volume: Registration file of 29,000 cards

Reference: Mary T. Howe and Mary K. Weidner, "Data Processing in the Decatur Public Library," Illinois Libraries, XLIV (November 1962), 593-97.

14. Southern Illinois University library

Status: Operational, except circulation

(1951)

Operations: Serials-budget records

$$
\begin{gathered}
\text { - current list } \\
\text {-acquisitions } \\
\text { Books - acquisitions } \\
\text { - budget records } \\
\text { - circulation }
\end{gathered}
$$

References: Alton P. Juhlin, "The Use of IBM Equipment in Order Procedures at Southern Illinois University Library," Illinois Libraries, XLIV (November 1962), 598-602.

"Automated Circulation Procedures at Southern Illinois University," Library Journal, LXXXVIII (March 15, 1963), 1133.

15. Illinois state library

Status: Experimental

Operations: Books-acquisitions

-bibliographies

-catalog (in book form)

-circulation

-shelf list

Volume: $\quad 30,000$ volumes circulated a month

$1,300,000$ volumes in collection

Reference: John G. W. McCord, “A Data Processing System for Circulation Control at the Illinois State Library," Illinois Libraries, XLIV (November 1962), 60307.

16. Pennsylvania State University library

Status: Experimental

Operations: Serials-acquisitions

Books - acquisitions -budget records
-KWIC index

-selective dissemination of information

Reference: Thomas Minder and Gerald Lazorick, "Automation of the Pennsylvania State University Acquisitions Department," Automation and Scientific Communications Proceedings, Part 3. (Washington, D.C.: American Documentation Institute, 1963), pp.455-59.

17. Monsanto Chemical Company Information Center, St. Louis, Missouri

Status: Operational (about 1961)

Operations: Serials-acquisition -complete holdings

Books-catalog (in book form)

-circulation

-budget records

-announcement lists

-bibliographies

Volume: $\quad 5,000$ titles in book catalog

Reference: W. A. Wilkinson, "A Machine-Produced Book Catalog: Why, How and What Next?" Special Libraries, LIV (March 1963), 137-43.

18. University of Missouri library

Status: Partly operational

Operations: Serials-acquisitions

-claiming

-budget records

Books - acquisitions

-shelf list

-circulation

-budget records

Reference: Ralph H. Parker, "Automatic

Records Systems at the University of Missouri Library," College and Research Libraries, XXIII (May 1962), 231-32, 264-65.

19. Washington University School of Medicine library

Status: Partly operational

Operations: Serials-acquisitions

-claiming

-bindery records 
-current lists

-complete holdings

-budget records

- circulation

Volume: $\quad 1,200$ serials titles

Reference: Irwin H. Pitzer, Donald R. Franz, and Estelle Brodman, "Mechanization of Library Procedures in the Medium-Sized Medical Library: The Serial Record," Medical Library Association Bulletin, LI (July 1963), 313-38.

20. IBM, Thomas J. Watson Research Center library, Yorktown Heights, New York

Status: Operational (Fall 1962)

Operations: Books-acquisitions

-in-process records

-shelf list

-announcement lists

- circulation

Volume: $\quad 20,000$ books

500 average weekly circulation

350 overdue notices sent out every two weeks

References: R. W. Gibson Jr., and G. E. Randall, "Circulation Control by Computer," Special Libraries, LIV (JulyAugust 1963), 333-38.

G. E. Randall and Roger P. Bristol, "PIL (Processing Information List) or a Computer-Controlled Processing Record," Special Libraries, LV (February 1964), 82-86.

21. University of Rochester, science and engineering libraries

Status: Operational

Operations: Books-catalog (in book form)

Serials-complete holdings

Volume: $\quad 4,000$ journal titles

Reference: Phyllis A. Richmond, "A Short-Title Catalog Made with IBM Tabulating Equipment," Library Resources and Technical Services, VII (Winter 1963), 81-90.
22. E. I. du Pont de Nemours and Company, technical library, Wilmington, Delaware

Status: Operational (about 1952)

Operations: Serials-complete holdings

-current list

-circulation

-routing

Volume: 1,183 periodical titles received

621 periodical titles circulated

Reference: Stella-Margaret Riggle, "Automatic Journal Routing Using IBM Punched Cards," Special Libraries, LIII (November 1962), 537-40.

23. General Electric Company, plant technical library (Hanford), Richland, Washington

Status: Operational

Operations: Serials -acquisitions

-complete holdings

Reports-announcement lists - catalog (on cards)

-inventory

-routing

Volume:

2,800 periodical subscriptions

$400,000-500,000$ reports in library $(195,000$ classified reports on tape)

15,000 deliveries and pickups of reports to users a month

Reference: Chris G. Stevenson, "Mechanization of Hanford's Technical Information Operation," The Literature of $\mathrm{Nu}$ clear Science: Its Management and Use (Oak Ridge, Tenn.: U.S. Atomic Energy Commission, Division of Technical Information Extension, 1962), pp.177-80.

24. University of California, San Diego, library

Status: Experimental

Operations: Serials-acquisitions

-claiming

-bindery records 
-current lists

-complete holdings

-want lists

-subscription expiration date

Volume: 712 serial titles in experiment

References: George Vdovin, "The Serials Computer Project, University of California, San Diego," Information Retrieval Today (paper presented at the institute conducted by the library school and the Center for Continuation Study, University of Minnesota, Minneapolis, September 19-22, 1962), pp.109-18.

University of California, San Diego, University Library and UCSD Computer Center: Report on Serials Computer Project (San Diego, Calif.: University of California, San Diego, 1962), 32p.

25. Long Island Lighting Company, Hicksville, New York (industrial)

Status: Operational (1st edition of printed catalog, March 1960)

Operations: Serials-complete holdings Books-catalog (in book form) -bibliographies

Reference: Charles A. Vertanes, "Automation Raps at the Door of the Library Catalog," Special Libraries, LII (MayJune 1961), 237-42.

\section{Discussion}

While a tabulation of the types of records that are now prepared with the aid of a machine is of interest, the reasons for utilizing such records, their advantages and disadvantages, and their cost of development and operation are perhaps more important to the librarian who has to decide whether to use such techniques in his own shop. These points will now be discussed.

Reasons for developing machine-based systems varied, but almost half of the installations (eleven out of twenty-five) gave as one of their reasons an increase in volume of work caused by either a higher acquisition rate or demand for more extensive service, or both, without corresponding increase in manpower. Twelve installations stated the need for more complete and up-to-date records or records in different forms and in multiple copies for different physical locations. Several installations expressed the need for an integrated record system to reduce bottlenecks as well as to achieve better control of operations. This, the librarians felt, could be obtained with machine-based records. Other reasons included a desire to experiment with more sophisticated systems, and availability of equipment.

All installations reported improvements in library service and eighteen out of twenty-five installations reported savings in either personnel or over-all costs. Improved services were achieved by several means. The speed and accuracy of the machine enabled the librarian to provide more up-to-date and accurate records both for the patron and for himself. The production of printed lists in a variety of ways, as exemplified by a list of journals received or a list of volumes at the bindery was now economically possible. Better control of library operations because of the existence of such lists was cited by fourteen installations as one reason for improved service. Lower costs in clerical operations were achieved by delegating some of the repetitive operations to the machine and by eliminating the manual duplication of records. Professionals were also relieved of some clerical details allowing them more time to work with the patron. In no instance, however, was the overall manpower reduced as a result of mechanization since time thus gained was used to improve or expand library services.

A number of disadvantages of machine records were brought out, although twelve out of twenty-five installa- 
tions did not dwell on this aspect of the system. The use of machines requires a carefully worked out operating procedure. Nothing can be implied or left to the imagination of the machine. Abbreviations and spacing, for example, must be standardized and filing rules must be indicated in detail. The effort required in working out such procedures was considered a disadvantage of mechanized records. The limited number of symbols on a printer and the limited amount of space on a machine-sorted punched card were also cited as disadvantages that necessitated a revision of traditional records. The library's dependence on somebody else's equipment with resulting inconvenience was also commented upon unfavorably. Finally, the high cost of developing the system and of converting existing records was also one of the cited disadvantages.

Even though the machine-based systems offer advantages over the manual systems it is important to know at what additional costs such advantages are achieved. The reports of the twenty-five installations are not fully informative on this point. Ten of the twenty-five installation reports give no cost information, and none of the installation reports gives the cost of developing the system (an admittedly difficult cost to collect but nonetheless a necessary item of information). Reports of only six installations gave comparative costs of the old manual and the new machine-based systems. Four of the installations stated that the machine-based systems cost less to operate than the manual systems, one machine-based system costs about the same to operate as does the manual system, and one machine-based system will cost slightly more to operate for the first five years and then will cost less than a manual system.

Before a new system can be put into operation, the existing system has to be analyzed and the specifications for a new system have to be established. These specifications have to be translated into operating procedures for both the manual and machine aspects of the system. The preparation of instructions for the machine (machine programs) may require one or more man-years. The new system is then tested, revised, and frequently maintained in parallel with the old system for a period of time. The development of a new system is thus time consuming and costly. This cost must be included in the over-all cost of operations.

What can be concluded from the experience of twenty-five libraries with machine-based records? There appears to be convincing evidence that carefully planned and executed machine-based systems can indeed improve the effectiveness and efficiency of library operations. Most of the installations studied have not been in operation sufficiently long so that all the advantages and disadvantages can be fully characterized. Experience to now indicates that a greater variety of records can be prepared more quickly and accurately and at a lower cost of operation (disregarding development cost) than manual systems. Some adjustments must be made to unfamiliar typography and different filing rules of such systems, to mention only two factors. It seems evident that an efficient machine-based system, just as an efficient manual system, must be based on a sound interpretation of the library's needs. The cost of determining such needs and the cost of formulating a system based on these needs is high (though it is not known at this point how high) for both manual and machine systems. System development costs will vary from library to library because of differences in record volume and record specifications. It is hoped that future case histories of library systems will include the cost of developing the system so that this information will be available to other librarians who are charged with developing a new or im- 
proved record system. The availability of this information along with the cost of operating the old and the new system will also facilitate the evaluation of the system. The use of data processing equipment for the preparation of library records appears to be most advantageous when one basic record can be used for a variety of functions, and when the cost of developing and operating the system can be shared by a number of libraries. This condition exists when data processing equipment is used for the preparation of acquisition, cataloging, circulation, and related records for a group of libraries with similar interests and needs.

\section{Index to Summarized Case Histories of} Twenty-Five Installations

\section{Type of library}

Government: 1, 4, 5, 8, 9, 10

Industrial: $2,3,6,7,17,20,22,23,25$

Public: $12,13,15$

University: 11, 14, 16, 18, 19, 21, 24

Types of records mechanized

\section{Books}

Accession list: 5, 6, 9, 20

Acquisitions: $5,11,13,14,15,16,18,20$

Analysis of readers' interests: 11,13

Announcement lists: 2, 6, 7, 9, 17, 20

Bibliographies: 2, 6, 11, 15, 17, 25

Budget records: $5,6,7,9,11,13,14,16$, $17,18,19$
Catalog: $2,5,6,7,8,9,11,12,13,15$, $17,21,25$

Circulation: $2,5,6,7,9,10,11,13,14$, $15,17,18,20$

In-process records: $5,11,20$

Keyword-in-content index: 7, 9, 16

Permuted index to Library of Congress subject headings: 11

Selective dissemination of information: 2 , $5,11,16$

Shelf list: $7,13,15,18,20$

Subject authority list: 9

Reports

Accession list: 5,7

Announcement lists: 5, 7, 23

Catalog: 5, 7, 23

Circulation: $5,7,9,10,23$

In-process file: 5

Inventory: 5, 23

Keyword-in-content index: 7

Routing: 23

Select dissemination of information: 5

Serials

Acquisitions: $1,4,5,6,9,11,14,16,17$, $18,19,23,24$

Bindery records: $3,5,9,11,19,24$

Budget records: $3,6,7,14,18,19$

Circulation: $3,9,10,13,19,22$

Claiming: $5,9,11,18,19,24$

Complete holdings: $1,4,5,6,11,12,13$, $17,19,21,22,23,24,25$

Current list: $1,3,4,6,9,11,14,19,22$, 24

Routing: 3, 5, 6, 22

Subscription expiration date: 7,24

Want list: 24

\section{REDUCED MULTIPLE COPY RATE FOR CHOICE}

\section{BOOKS FOR COLLEGE LIBRARIES}

Beginning with Volume 2, March 1965, additional copies to the same address are $\$ 10.00$. The original subscription remains $\$ 20.00$.

Single or multiple subscriptions should be sent to the American Library Association Subscription Department, 50 East Huron Street, Chicago, Illinois 60611. 